\title{
ВСЕРОССИЙСКАЯ НАУЧНАЯ КОНФЕРЕНЦИЯ «ЧЕЛОВЕК ПЕРЕД ВЫБОРОМ В СОВРЕМЕННОМ МИРЕ: ПРОБЛЕМЫ, ВОЗМОЖНОСТИ, РЕШЕНИЯ»
}

\author{
Вал. А. Луков \\ (Московский гуманитарный университет)
}

\begin{abstract}
Аннотация: В статье дан обзор работы Всероссийской научной конференции «Человек перед выбором в современном мире: проблемы, возможности, решения», которая прошла 27-28 ноября 2015 г. в Институте философии РАН при поддержке в том числе Института фундаментальных и прикладных исследований Московского гуманитарного университета.
\end{abstract}

Ключевые слова: конференция; обзор; проблема выбора; антропология, философия

\section{ALL-RUSSIA RESEARCH CONFERENCE \\ "FACING CHOICE IN CONTEMPORARY WORLD: ISSUES, OPPORTUNITIES, SOLUTIONS"}

\author{
Val. A. Lukov
}

(Moscow University for the Humanities)

Abstract: This is an overview of the all-Russia conference "Facing choice in contemporary world: issues, opportunities, solutions" which took place on November 27-28, 2015 at the Institute of Philosophy, Russian Academy of Sciences, with support, among others, from the Institute of Fundamental and Applied Studies, Moscow University for the Humanities.

Keywords: conference; overview; problem of choice; anthropology; philosophy

27-28 октября 2015 г. в Институте философии РАН состоялась Всероссийская научная конференция «Человек перед выбором в современном мире: проблемы, возможности, решения». Конференция, которая проводилась при грантовой поддержке РГНФ (проект № 15-03-14037 г), была организована Институтом философии РАН, философским факультетом Новосибирского государственного университета, кафедрой философии религии и религиоведения Санкт-Петербургского государственного университета, Институтом фундаментальных и прикладных исследований Московского гуманитарного университета.

Конференцию открыл директор Института философии РАН, акаде- 
мик РАН А. А. Гусейнов. С докладами на пленарном заседании выступили М. С. Киселева, доктор философских наук, профессор, зав. сектором методологии междисциплинарных исследований человека ИФ РАН («Междисциплинарная проективность выбора человека»), Д. А. Леонтьев, доктор психологических наук, зав. международной лабораторией позитивной психологии личности и мотивации НИУ ВШЭ («Проблема выбора в науках о человеке: от рациональных моделей к экзистенциальным», П. И. Сидоров, академик РАН, Северный государственный медицинский университет Минздрава РФ (Архангельск) «Парадигма выбора в интерфейсе системы общественного сознания и ментальных эпидемий», П. С. Гуревич, доктор философски наук, профессор, главный научный сотрудник сектора истории антропологических учений ИФ РАН («Цивилизационный выбор в эпоху глобализации»). Вал. А. Луков, доктор философских наук, профессор, заслуженный деятель науки РФ, директор Института фундаментальных и прикладных исследований МосГУ «Молодежь в ситуации выбора» (Луков, 2015), Т. В. Чумакова, доктор философских наук, профессор кафедры философии религии и религиоведения СПбГУ («Религиозные аспекты выбора человека как область междисциплинарных исследований), В. С. Диев, доктор философских наук, профессор, декан философского факультета Новосибирского государственного университета («"Принятие решений” как междисциплинарная сфера исследований: философские и методологические предпосылки»). Состоялось оживленное обсуждение докладов, в том числе по вопросам, связанным с особенностями выбора молодежью своего пути в современном мире, перспективами ее самореализации в обществе.

Это обсуждение было продолжено на заседаниях секций конференции, в том числе секции «Молодежь в ситуации выбора», руководителем которой был Вал. А. Луков. Саморегуляции выбора в условиях изменяющейся социальной реальности посвятила свое выступление Ю.А.Зубок, доктор социологических наук, профессор, зав. отелом социологии молодежи ИСПИ РАН (Зубок, 2015). В. А. Гневашева, доктор экономических наук, доцент, директор Центра социологии молодежи Института фундаментальных и прикладных исследований МосГУ охарактеризовала динамику изменений социальных и культурных ценностных ориентаций российской молодежи (Гневашева, 2015). Интерес вызвала трактовка условий выбора молодежи, которую в своем выступлении представил И.И. Сулима, доктор философских наук, доцент, профессор кафедры философии Нижегородского госпедуниверситета (Сулима, 2015). О результатах исследований, проведенных среди студентов МИФИ в 2006 и 2014 гг., сообщили И. И. Ашмарин, кандидат физико-математических наук, доцент, старший научный сотрудник ИФ РАН, доцент НИЯУ МИФИ и Г. Б. Степанова, кан- 
дидат психологических наук, старший научный сотрудник ИФ РАН (Ашмарин, Степанова, 2015).

Ч. К. Ламажаа, доктор философских наук, заместитель директора Института фундаментальных и прикладных исследований МосГУ, обратилась к региональным аспектам молодежного выбора и охарактеризовала вехи развития и современные проблемы социологических исследований в Туве (Ламажаа, 2015). Е. И. Ярославцева, кандидат философских наук, доцент, старший научный сотрудник ИФ РАН свое выступление посвятила «поколению сетевой генерации», показав его в ракурсе выбора неустойчивой идентичности (Ярославцева, 2015). С этим сообщением оказалась близка тема выступления Т. А. Симоновой, кандидата философских наук, доцента Института менеджмента и права, ассистента Института социальных и политических наук Уральского федерального университета, которое было посвящено такому новому явлению в молодежной среде, как «социальный серфинг», охарактеризованный как «выбор не выбирать» (Симонова, 2015).

В выступлениях участников секции были подняты многие актуальные вопросы социально-философского осмысления, социологического изучения новых явлений в молодежной среде. О значении такой работы, проводимой в различных научных и образовательных организациях России, и прежде всего в Институте социально-политических исследований, Институте социологии, Институте философии РАН, Московском гуманитарном университете, НИУ ВШЭ, МГУ им. М. В. Ломоносова, университетов в Санкт-Петербурге, Екатеринбурге, Барнауле, Красноярске и других российских центрах исследования молодежных проблем, в заключительном слове говорил Вал. А. Луков, обозначивший перспективные направления исследований молодежи в ключе социальной философии, философии культуры, социологии молодежи и более широко - в русле междисциплинарных исследований, объединяющих ресурсы как социальных и гуманитарных, так и естественных наук.

Материалы конференции были опубликованы в трех томах сборника (Человек перед выбором ..., 2015).

\section{СПИСОК ЛИТЕРАТУРЫ}

Ашмарин, И. И., Степанова, Г. Б. (2015) Студенты об инновационной деятельности: вчера и сегодня // Человек перед выбором в современном мире: проблемы, возможности, решения. Материалы Всероссийской научной коференции 27-28 октября 2015 г., ИФ РАН (Москва) : в 3 т. / отв. ред. М. С. Киселева. М. : Научная мысль. Т. 2. С. 213-233.

Гневашева, В. А. (2015) Социальные и культурные ценностные ориентации российской молодежи: динамика изменений // Человек перед выбо- 
ром в современном мире: проблемы, возможности, решения. Материалы Всероссийской научной коференции 27-28 октября 2015 г., ИФ РАН (Москва) : в 3 т. / отв. ред. М. С. Киселева. М. : Научная мысль. Т. 2. С. 189-197.

Зубок, Ю. А. (2015) Молодежь в изменяющейся социальной реальности: проблема саморегуляции выбора // Человек перед выбором в современном мире: проблемы, возможности, решения. Материалы Всероссийской научной коференции 27-28 октября 2015 г., ИФ РАН (Москва) : в 3 т. / отв. ред. М. С. Киселева. М. : Научная мысль. Т. 2. С. 173-188.

Ламажаа, Ч. К. (2015) Молодежь Тувы в ситуации выбора: вехи развития и современные проблемы социологических исследований тувинской молодежи // Человек перед выбором в современном мире: проблемы, возможности, решения. Материалы Всероссийской научной коференции 27-28 октября 2015 г., ИФ РАН (Москва) : в 3 т. / отв. ред. М. С. Киселева. М. : Научная мысль. Т. 2. С. 268-276.

Луков, В. А. (2015) Молодежь в ситуации выбора // Человек перед выбором в современном мире: проблемы, возможности, решения. Материалы Всероссийской научной коференции 27-28 октября 2015 г., ИФ РАН (Mосква) : в 3 т. / отв. ред. М. С. Киселева. М. : Научная мысль. Т. 2. С. 158-172.

Симонова, Т. А. (2015) Социальный серфинг: выбор не выбирать // Человек перед выбором в современном мире: проблемы, возможности, решения. Материалы Всероссийской научной коференции 27-28 октября 2015 г., ИФ РАН (Москва) : в 3 т. / отв. ред. М. С. Киселева. М. : Научная мысль. Т. 2. С. 264-267.

Сулима, И. И. (2015) Условия выбора молодежи: проблемы // Человек перед выбором в современном мире: проблемы, возможности, решения. Материалы Всероссийской научной коференции 27-28 октября 2015 г., ИФ РАН (Москва) : в 3 т. / отв. ред. М. С. Киселева. М. : Научная мысль. Т. 2. С. 206-212.

Человек перед выбором в современном мире: проблемы, возможности, решения (2015). Материалы Всероссийской научной коференции 2728 октября 2015 г., ИФ РАН (Москва) : в 3 т. / отв. ред. М. С. Киселева. М. : Научная мысль.

Ярославцева, Е. И. (2015) Поколение сетевой генерации: выбор неустойчивой идентичности // Человек перед выбором в современном мире: проблемы, возможности, решения. Материалы Всероссийской научной коференции 27-28 октября 2015 г., ИФ РАН (Москва) : в 3 т. / отв. ред. М. С. Киселева. М. : Научная мысль. Т. 2. С. 249-263.

Луков Валерий Андреевич - доктор философских наук, профессор, директор Института фундаментальных и прикладных исследований Московского гуманитарного университета, заслуженный деятель науки Рос- 
сийской Федерации, вице-президент Международной академии наук (IAS, Инсбрук, Австрия), академик Международной академии наук педагогического образования. Адрес: 111395, Россия, г. Москва, ул. Юности, д. 5. Тел.: +7 (499) 374-75-95. Эл. адрес: v-lukov@list.ru

Lukov Valery Andreevich, Doctor of Philosophy, Professor, Director, Institute of Fundamental and Applied Studies, Moscow University for the Humanities; Honored Scientist of the Russian Federation; Vice President, International Academy of Science (Innsbruck, Austria); Full member, International Teacher's Training Academy of Science. Postal address: 5 Yunosti St., 111395 Moscow, Russian Federation. Tel.: +7 (499) 374-75-95. E-mail: v-lukov@list.ru 